\title{
From ISET to InDRE. II. Sanitary and Tropical Diseases Institute: maturity and consolidation, 1940-1964
}

Jorge Alejandro Ramírez-Hernández, ${ }^{1}$ María del Carmen Guzmán-Bracho, ${ }^{2 *}$ Carlos Viesca-Treviño ${ }^{1}$ José Alberto Díaz-Quiñonez ${ }^{2}$

${ }^{1}$ Universidad Nacional Autónoma de México, Faculty of Medicine; ${ }^{2}$ Epidemiological Diagnostic and Reference Institute. Mexico City, Mexico

\begin{abstract}
\end{abstract}
The period that starts in 1940 is crucial for the creation of Mexico's modern health system. Sanitary and Tropical Diseases Institute is the pioneer institution in health research and on its first two decades it achieved maturity and consolidated linês of research expressed in almost 1700 publications. It also obtained notorious international visibility and was selected as a regional reference for epidemiological surveillance of influenza, streptococcus and salmonella. Its evolution took place with an $\underline{\text { inno- }}$ vation rhythm that would be decreasing by the end of this period. It faced limitations to renew lines of research, researchers and laboratory equipment. However, its role in public health decisions of the country remained central.

KEY WORDS: Sanitary and Tropical Diseases Institute. History of medicine. Public health

\section{Introduction}

In 1935, the construction of the Sanitary and Tropical Diseases Institute (ISET - Instituto de Salubridad y Enfermedades Tropicales) building was started, on a piece of land called Quinta de San Ramón (Figure 1). ${ }^{1}$

The area where it was set up had been declared of public utility in 1934, for the construction of various buildings approved by the Federal District Planning Commission to "the benefit of public health", among other intangible social benefits proposed in the expropriation decree of the properties known by the names of Rancho Nextitla and Quinta de San Ramón. ${ }^{2}$

In that area, at Mexico City northwest, the most important period of transformation of the landscape in the post-revolutionary era began in those days. ${ }^{3} \mathrm{An}$ educational and health hub was integrated in a polygon, which currently is formed by the Mexico-Tacuba Avenue, Instituto Técnico Industrial Internal Circuit and Los Gallos Avenue. In the 1946-1964 period, the facilities of the "Lázaro Cárdenas" Professional Unit of the National Polytechnic Institute (1936), , the "Rubén Leñero" Hospital (1943), ${ }^{4}$ the Institute of Virology, the Women's Hospital $(1955)^{5}$ and the facilities that hosted the ISET (now Institute of Diagnostic and Epidemiological Reference) from 1935 to 2013 were included.

The architectural ensemble of the area startedकobeing built with the style of the 1930's and 1940's; apthe Superior Normal School and the ISET, traces of $2 u$ ropean Bauhaus and Art Deco are identified.

The name of the Institute was made up of three terms:

- Instituto (Institute) (institūtum, "rule", "teaching"), which is a term that had been previously usedfor health organizations in Mexico, as in National Medical Institute, Pathology Institute, Bacteriological Institute/Institute of Hygiene, in the style of European and North American institutions. Therefore, it was profiled an institution dedicated to research.

- Salubridad (Sanitary) (salubritas, "good general health") is a key concept in the area of health in Mexico since the establishment of the Consejo Superior de Salubridad (Higher Council of Sanitary),
Correspondence:

*María del Carmen Guzmán-Bracho

E-mail: cguzmanbracho@ hotmail.com
Date of reception: 12-04-2019

Date of acceptance: 02-05-2019

DOI: 10.24875/GMM.M19000303

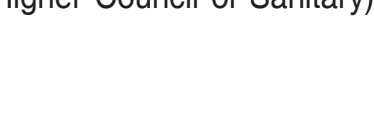

Gac Med Mex. 2019;155:360-366

Contents available at PubMed www.gacetamedicademexicer.com 


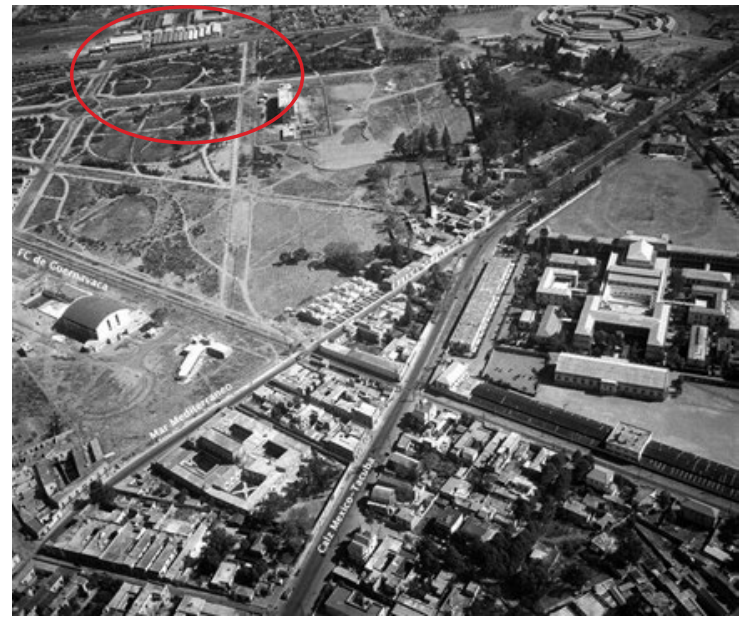

Figure 1. ISET under construction, 1935. It is a unique building, in a space dedicated to health care. Photograph available online. Original belonging to the ICA Air Photography Collection.

which was the governing body in this area since 1841, refurbished in 1917 as Departamento de Salubridad Pública y Consejo de Salubridad General (Department of Public Health and General Salubrity Council). ${ }^{6}$

- Enfermedades tropicales (tropical diseases), is a notion of colonial source from late $19^{\text {th }}$ century, which acknowledged the association between the geographic environment and health conditions of a population. Malaria, leishmaniasis, onchocerciasis and Chagas disease are examples of tropical diseases with epidemiological impact in Mexico.

In the period from 1940 to 1964 , infectious diseases were the leading cause of death. Whooping cough and malaria were important causes of morbidity and mortality in the first half of the $20^{\text {th }}$ century, ${ }^{7}$ in addition to gastrointestinal and respiratory tract conditions. However, distribution and application of the smallpox vaccine, the introduction of penicillin and other antibiotics clinical use, the application of DDT as a pesticide, in addition to the implementation of basic sanitation, nutrition and legislation measures ${ }^{8}$, modified the pattern of diseases that were the cause of death in the population ${ }^{9}$ (Table 1).

\section{Second six-year plan}

In the six-year term that began in 1940, intense infrastructure design and construction activity was developed by the Ministry of Assistance, as well as legislation that would lead to the creation of the Mexican Institute of Social Security. In the work report of Gustavo Baz, ${ }^{10}$ Secretary of Public Assistance, submitted to the $\mathrm{H}$. Executive of the Union for the 1941-1942 period, the work of the hospital technical commissions and their construction plans and assistance units were outlined. The general hospital model that was taken as a basis was the vertical hospital in the manner of those existing in the United States, where basic clinical services were offered, with laboratories and medical files departments, in addition to being teaching centers. All this within the formula "the hospital is at the same time a scientific center, a hotel, an industrial plant and a school."10 In those days, general hospitals were under čnstruction throughout the country, as well as the $\mathrm{Na}$ tional Institute of Cardiology and the Children's Fospital. The land was being acquired for the construction of the National Medical Center at Colonia de los Doctores, in Mexico City. ${ }^{6}$

\section{A new model of hospital and research institute}

The Hospital Plan, conceived by Gustavo Baz, defines the key elements hospital facilities should have. Several hospitals and specialty institutes arise that will compete to be leaders of this nascent health care network. With the National Institute of Cardiology, three new points in its relationship with the Sanitary and Assistance Secretariate were established:"

- Certain governance autonomy.

- Part of the service could be used by private patients.

- Its legislative situation allowed the reception of donations.

In 1943, two events occurred that were fundamental for the country's health:

- The Secretariate of Assistance absorbed the Sanitary Department, to become the Ministry of Sanitary and Assistance Secretariate (SSA Secretaría de Salubridad y Asistencia).

- The legislation for the creation of the Mexican Institute of Social Security was approved, which started operating in 1944. ${ }^{12,13}$

This way, Gustavo Baz, first Public Health -and Assistance minister, became the most influential Mexican doctor of the post-revolutionary era. Probably no country in the process of industrialization in the world, during the war, undertook a comparable effort for health care. With this creative impetus in Mexico, the new health institutes were created under different criteria than those of the ISET. 
Table 1. Fifteen leading causes of death in Mexico ${ }^{9}$

\begin{tabular}{|c|c|c|c|c|}
\hline No. & 1930 & 1940 & 1950 & 1960 \\
\hline 1 & Diarrhea and enteritis & Diarrhea and enteritis & $\begin{array}{l}\text { Gastritis, duodenitis, enteritis } \\
\text { and colitis, except for diarrhea in } \\
\text { newborns }\end{array}$ & $\begin{array}{l}\text { Gastritis, duodenitis, enteri } \\
\text { colitis, except for diarrhea } \\
\text { newborns }\end{array}$ \\
\hline 2 & Influenza and pneumonia & Influenza and pneumonia & Influenza and pneumonia & Influenza and pneumonia \\
\hline 3 & Malaria & Malaria & Early childhood diseases & Early childhood diseases \\
\hline 4 & Whooping cough & Accidents or violent deaths & Accidents or violent deaths & Accidents or violent deaths \\
\hline 5 & Accidents or violent deaths & $\begin{array}{l}\text { Congenital deformations and } \\
\text { early childhood diseases }\end{array}$ & Malaria & Heart diseases \\
\hline 6 & Smallpox & Measles & Heart diseases & Malignant tumors \\
\hline 7 & Measles & Bronchitis & Whooping cough & Bronchitis \\
\hline 8 & $\begin{array}{l}\text { Congenital weakness, } \\
\text { congenital malformations }\end{array}$ & Liver and bile duct diseases & Tuberculosis (AF) & Tuberculosis (AF) \\
\hline 9 & Tuberculosis (AF) & Tuberculosis (AF) & Bronchitis & Liver cirrhosis \\
\hline 10 & Liver and bile duct diseases & Heart diseases & Measles & Malaria \\
\hline 11 & Bronchitis & Whooping cough & Malignant tumors & $\begin{array}{l}\text { Vascular lesions that affect } \\
\text { central nervous system }\end{array}$ \\
\hline 12 & Heart diseases & $\begin{array}{l}\text { Typhoid and paratyphoid } \\
\text { fever }\end{array}$ & Liver cirrhosis & Measles \\
\hline 13 & $\begin{array}{l}\text { Typhoid and paratyphoid } \\
\text { fever }\end{array}$ & Nephritis & Nephritis and nephrosis & Dysentery (AF) \\
\hline 14 & Nephritis & Malignant tumors & Dysentery (AF) & Whooping cough \\
\hline 15 & $\begin{array}{l}\text { Cerebral hemorrhage, } \\
\text { embolism or thrombosis }\end{array}$ & $\begin{array}{l}\text { Cerebral hemorrhage, } \\
\text { embolism or thrombosis }\end{array}$ & Typhoid fever & Anemia \\
\hline
\end{tabular}

\section{Where was the ISET located in this period?}

On one hand, the ISET had no autonomy and was governed by the SSA general legislation, with rigid financing and minimal recovery fees for its clinical and laboratory services. Owing to this, the Institute would be left at disadvantage to compete and drive innovative research, to attract new generations of researchers and to renew the laboratory equipment and furniture.

\section{Changes in Mexican economy}

Mexican economy was transformed during Manuel Ávila Camacho's six-year term. ${ }^{12,13} \mathrm{~A}$ policy of stimulus and support to the private sector, which had been distrustful on Lazaro Cárdenas administration, was applied, which enabled the return of private investment to the country. ${ }^{12}$

In 1941, the United States entered the war and relaxed its relationship with Mexico, which had hardened

as a result of the oil industry nationalization. The United States granted loans to Mexico for the development of its industry and increased imports from our country. In turn, the Mexican State offered five tax-free year's to new industries as an incentive to support them. The Bank of Mexico made the official regulation and Nacional Financiera opened new lines of credit. National companies emerged in the areas of steel, glass, cement, manure and fertilizers; the railway sector and the oil industry, among others, were strengthened ${ }_{s}^{8-1}-12$

This, coupled with the limitation that the World $\$$ War caused in exports from Europe to the United States, allowed Mexico to start filling that place and the State to strongly support the country's industrialization. Thus, an effect consisting of the North American economy pulling the Mexican was generated, with the consequent economic growth, which allowed to expand health infrastructure.

Workers of the new national industry obtained their health care at the Mexican Institute of Social Security, thus easing financial weight on the SSA. 
“ (3) establishes a Technical Preparatory Committee to prepare a draft annotated agenda and proposals for the consideration of the Conference, and appoints the following experts or their alternates to constitute the Committee :

I. Dr. Gregorio Berman (Argentina)

2. Dr. René Sand (Belgium)

3. Dr. Geraldo H. DE Paula Souza (Brazil)

4. Major-General G. B. Chrsholm (Canada)

5. Dr. P. Z. KING (China) (alternate: Dr. Szeming Sze)

6. Dr. Josef Čnčrk (Czechoslovakia)

7. Dr. Aly Tewfik Shousha Pasha (Egypt)

8. Dr. A. Cavaillon (France) (alternate: Dr. Leclainche)

9. Dr. KopanaRIS (Greece)

ro. Major C. MANI (India) (alternate: Dr. Chuni LAL Katial)

II. Dr. Manuel Martinez Baez (Mexico)

I2. Dr. Karl Evang (Norway)

13. Dr. Martin KaCPRZAK (Poland)

14. Sir Wilson Jameson (United Kingdom) (alternate: Dr. Melville MACKENZIE)

15. Surgeon-General Thomas PARRAN (United States of America) (alternate: Dr. James A. DoulL)

16. Dr. Andrija Stampar (Yugoslavia)

and, in a consultative capacity, representatives of :

Figure 2. Constitution of the World Health Organization. Technical Preparatory Committee. The United Nations Economic and Social Council, derived from a resolution dated February 15, 1946, convened the International Health Conference for the establishment of the World Health Organization.

\section{Promotion of research at ISET}

There are clear examples of ISET's international reach through its presence in research and in health policies. In 1946, Luis Mazzotti took a six-month study trip across nine countries in Africa and the Middle East. ${ }^{14} \mathrm{His}$ purpose was to know in situ how they faced the problems of some infectious diseases at research centers and hospitals at the European colonies of Egypt, Arabian Africa (Tunisia, Algeria), Black Africa (Sudan, Uganda, Kenya, Belgian Congo, Equatorial Africa) and South Africa. Mazzotti had access to interesting studies on viruses -not published to that dateand received training on cultivation of parasites and arthropods, clinical identification and laboratory diagnosis for diseases such as typhus, trypanosomiasis, visceral leishmaniasis, schistosomiasis and syphilis; he reviewed in detail the elimination strategies and campaigns against Anopheles, yellow fever, uncinariasis, schistosomiasis, onchocerciasis and, in particular, he studied environmental and rural sanitation. It was a different trip from those accustomed by doctors of his generation, who attended academic centers in Europe and the United States. On his visit, Luis Mazzotti observed the situation in the lowest income countries in the world and analyzed the strategies that colonialist countries used in the face of infectious diseases.

At the other end of ISET international activity, the United Nations Economic and Social Council organized in 1946 an International Health Conference to propose an international health organization dependent on the United Nations, in recognition of the urgent need for international action in the field of public health. Some member countries were invited to send experts in public health. Mexico was represented by Manuel Martínez Báez, then Under-Secretary of Health and Assistance, who shortly before had been ISET director (Figure 2); he was member of the Technical Preparatory Committee of the constitution ofthe World Health Organization. ${ }^{15}$

Both these international activities constitute ancexample of two institutional profiles, local and global.

ISET important scientific work was also reflected on several high-specialty areas that were create $\phi$ in those days. In 1951, the director of the Pan American Health Organization incorporated Mexico along with Chile, in Latin America, to influenza global surveillance. ISET became the first National Influenza Genter in Latin America, one year before the creation of the Global Influenza Surveillance and Response System that integrated the National Influenza Centers with the purpose to monitor the circulation of viruses, identify their pandemic potential and update the annual composition of the vaccine (Figure 3).

Other recognized ISET instances included the 'Salmonella Center in Mexico and the Center for the Typing of Streptococci, which had regional responsibility. ${ }^{16,17} \mathrm{~A}$ very important work was carried out at the Mycology 

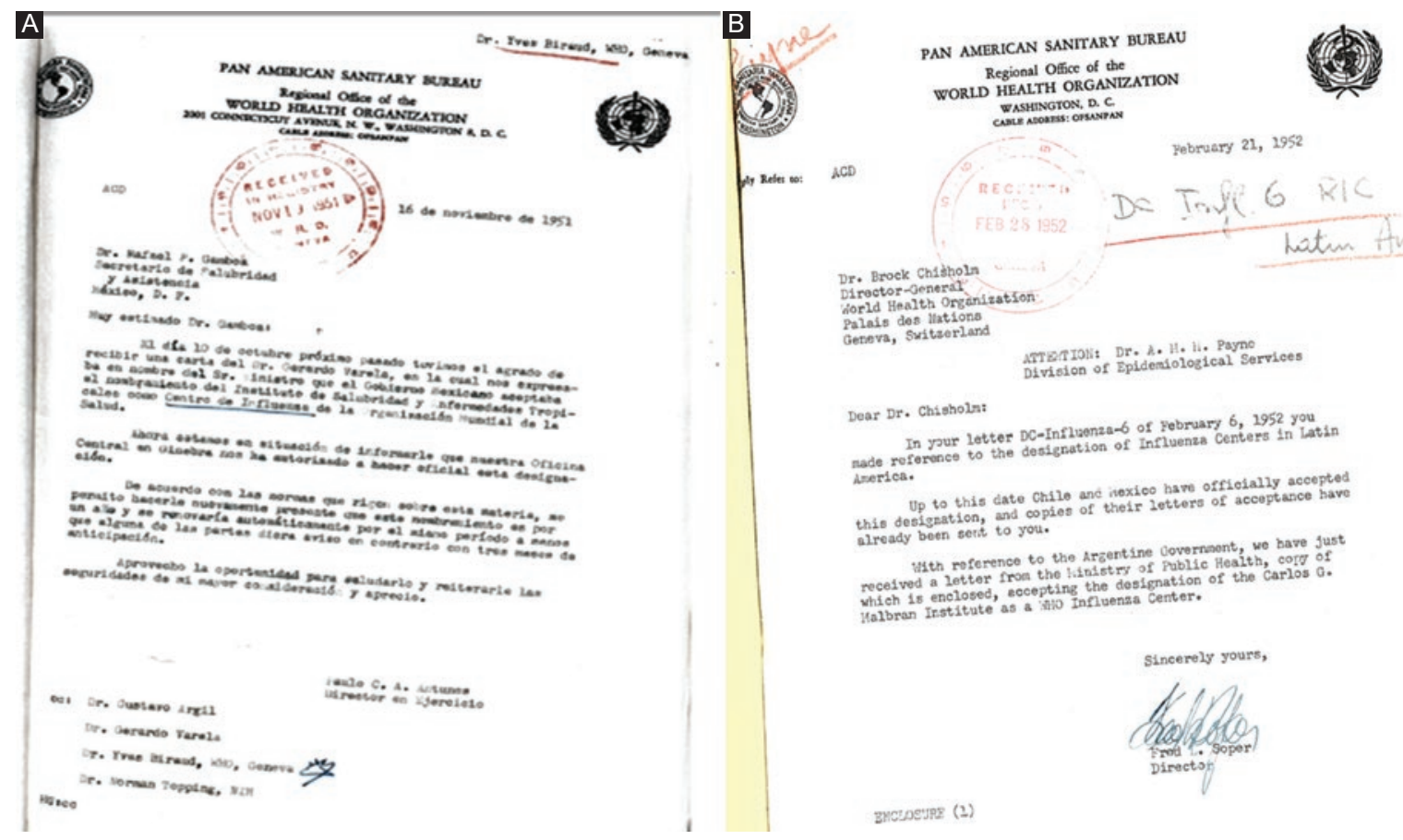

Figure 3. ISET, Influenza Center in Latin America. A) ISET designation, 1951. B) Notification of the designation to the World Health Organization, 1952.

Laboratory and the Tropical Dermatology Clinic, with research on etiologic agents and daily review of clinical cases by Antonio González Ochoa (C. Contreras, personal communication), considered the initiator of research on medical mycology in Mexico, with the support of world-impact publications.

In 1954, the project to establish a virology-specific laboratory was presented, although since early in that decade the Institute had been carrying out tissue cultures, isolation and serological viral recognition (enterovirus, poliovirus), maintenance of poliovirus strains, as well as diagnostic tests and isolation of the rabies virus. ${ }^{18}$

\section{Directorate of the Institute}

This successful institution was initially directed by a board of directors composed of researchers who were heads of laboratory and chaired by the director. ${ }^{19}$ In the 24-year period covered by this article, the ISET was chaired by its four main founder researchers and José Zozaya ${ }^{20}$ (Table 2).

\section{National and international publications ${ }^{21}$}

Since the first year of operation, ISET started publishing a journal of its own, which appeared regularly with the name Revista del Instituto de Salubridad

Table 2. Sanitary and Tropical Disease Institute

\begin{tabular}{l} 
Director \\
\hline Eliseo Ramírez Ulloa \\
Manuel Martínez Báez \\
Eliseo Ramírez Ulloa \\
Manuel Martínez Báez \\
Miguel E. Bustamante Vasconcelos
\end{tabular}

y Enfermedades Tropicales (Journal of the Sanitary and Tropical Diseases Institute) (Revista ISET), from November 1939 to December 1965, when it changed its name to Revista de Investigación en Salud Pública (Journal of Research in Public Health) with the Hindication "Former Journal of the Sanitary and Tropical Diseases Institute". ${ }^{22}$ The ISET Journal publishedpart 
Table 3. Published papers by researchers of the Sanitary and Tropical Diseases Institute between 1939 and 1964

\begin{tabular}{|c|c|c|c|c|}
\hline & Author & $\begin{array}{l}\text { ISET } \\
\text { journal }\end{array}$ & $\begin{array}{c}\text { Other } \\
\text { journals* }\end{array}$ & Total \\
\hline 1 & L. Vargas & 117 & 130 & 247 \\
\hline 2 & E. Roch & 13 & 228 & 241 \\
\hline 3 & G. Varela & 101 & 82 & 183 \\
\hline 4 & L. Mazzotti & 100 & 76 & 176 \\
\hline 5 & A. González Ochoa & 52 & 71 & 123 \\
\hline 6 & E. Beltrán & 48 & 62 & 110 \\
\hline 7 & M. Martínez Báez & 17 & 86 & 103 \\
\hline 8 & A. P. León & 41 & 33 & 74 \\
\hline 9 & E. C. Del Pozo & 6 & 67 & 73 \\
\hline 10 & M. E. Bustamante & 28 & 26 & 54 \\
\hline 11 & A. Díaz Nájera & 37 & 9 & 46 \\
\hline 12 & M. González Rivera & 7 & 31 & 38 \\
\hline 13 & M. A.Bravo Becherelle & 15 & 21 & 36 \\
\hline 14 & J. Zozaya & 26 & 3 & 29 \\
\hline 15 & S. C. Campillo & 9 & 17 & 26 \\
\hline
\end{tabular}

*97 different national and international journals, book chapters, newsletters, etc., are included

of the profuse work of the Institute researchers. Up to 1964, there were 702 articles by 266 authors, where the participation of international researchers, temporary guests of the institution, is identified, including Robert Hegner, Herman Mooser, Emile Brump, Ernest Faust, Todd Hewitt and Norman Stoll, as well as the collaboration of ISET members with national researchers from other agencies. Between 1939 and 1964, Luis Vargas, Gerardo Varela and Luis Mazzotti published more than one hundred articles each, with an average of five per year, in Revista ISET alone (Table 3). Works published in this journal and in 97 and more, cover various areas of interest in public health, such as medical geography, epidemiology, immunological topics, clinical behavior, treatment strategies, biology and susceptibility to antimicrobials, taxonomy and vector control. ${ }^{23}$

The reported results ${ }^{16,17,24}$ are the product of:

- Experimental activities in the laboratory and with data obtained in the processing of samples with different analytical tests.

- Intense clinical work and treatment of tropical diseases and in patients with deep and dermatological mycosis.
- Close collaborative work with National Campaigns and "application programs" (vector-transmitted diseases, pinta, brucellosis, diarrhea and characteristic diseases of childhood, polio, venerealdisiseases, among others).

- Special studies in endemic or epidemic risk areas throughout the country (Chagas disease, onehocerciasis, malaria, histoplasmosis, leishmaniasis, rickettsiosis, helminthiasis, among others).

\section{Conclusions}

In the 1940-1964 period, ISET was the pioneer institution of interdisciplinary health research in Mexico, developing basic, clinical, entomological, and epidemiological aspects with repercussion on the counfry's health campaigns. It achieved an extraordinary impetus and productivity during its first decades of work to later gradually start slowing down its pace of innovation and staff and laboratory equipment renovation. As of 1943, other health research institutions emerged, with different institutional agreements to those of ISET, with greater autonomy and resource management capacity. In addition, under these circumstances of economic growth for the country, the Sanitary and Assistance Secretariate, as well as the Mexican Institute of Social Security were created; the former produced the Plan of Hospitals, and it became imperative to have a hospital model and a proper discourse to motivate and to channel the generation and reproduction of medical and nursing knowledge, as well as of other health-related professions. The nascent institutes also offered attractive clinical career opportunities with higher-income potential than full-time research on topics related to public health and tropical diseases.

However, the ISET multiplied its activities and doecame central to important decision-making in the country's public health regarding problems of the infectious type. It acquired international notoriety and obtained formal regional appointments, as it occurred with influenza, salmonella and streptococci.

In an interesting contribution, doctor and historian Fernando Martínez Cortés analyzes the birth, vö cation and leadership of both ISET and the National Institute of Cardiology: 25

[The ISET] ... is born with the express purpose of contributing to health problems that afflict the country, among which the so-called tropical diseases constitute an important part. We can claim that this institution is the answer to an ideology, to a political project aimed at improving Mexicans' health. 
Conversely, the National Institute of Cardiology, inaugurated by President Manuel Ávila Camacho, is born from an eminently curative medical specialty and is created to investigate and to teach, with the most advanced means, the problems of that specialty (...) without heart diseases being a significant national health problem, with Dr. Chávez personality on their side, they brought official and private support together.

The ISET reached a high point of maturity, institutional consolidation and international recognition in this period.

\section{Acknowledgements}

To the ICA Foundation Air Photography Collection, for validating the ownership of the original photograph of the ISET under construction in 1935, as well as for validating the date it was taken. To the authorities and staff of the Secretariate of Health Historical Archive, for selflessly sharing their knowledge and for their valuable guidance in reviewing the files. To José Luis Garnica Carreño, Library and Information Networks for Knowledge, for the assistance provided at the World Health Organization headquarters in Geneva, Switzerland.

\section{References}

1. Calvillo-Velasco M, Valencia-Flores AO. El Cuadrilátero, recinto histórico. La formación de un ícono de identidad del Instituto Politécnico Nacional (1922-1914). México: Instituto Politécnico Nacional; 2015.

2. Decreto que declara de utilidad pública la expropiación de los predios Rancho Nextitla y Quinta de San Ramón, ubicados en la ex-municipalidad de Tacuba de Morelos. México: Diario Oficial de la Federación; 1934.

3. Molina-Palestina O. Breve historia y relación del patrimonio tangible de la delegación Miguel Hidalgo. México: Delegación Miguel Hidalgo; 2012.

4. Fajardo-Ortiz G. Dr. Rubén Leñero Ruiz (1902-1942): un hospital lleva su nombre. Bol Mex Hist Fil Med. 2002;5:27-28.
5. Secretaría de Salud. Historia del Hospital de la Mujer. México: Secretaría de Salud. 2018.

6. Bustamante ME, Viesca-Treviño C, Villaseñor F, Vargas-Flores A, Castañón R, Martínez-Barbosa X. La salud Pública en México. 1959 México: Secretaría de Salubridad y Asistencia; 1982.

7. Fernández-De Castro J, Fernández-De Castro H. Epidemias y endênias de México en el siglo XX. México: Siglo XXI Editores; 2015.

8. Ávila-Camacho M. Primer informe de gobierno. México: Congreso-de la Unión; 1941.

9. Almada-Bay I. La mortalidad en México. Colección Salud y Seguridad Social. Serie Manuales Básicos y Estudios. México: Instituto Mexicano del Seguro Social; 1982.

10. Baz G. Informe de Labores presentado al H. Ejecutivo de la tỷnión. México: Secretaría de Asistencia Pública; 1941-1942.

11. Chávez-Rivera I. Instituto Nacional de Cardiología Ignacio Cháveżeinco décadas de historia. 1944-1994. México: Editorial Médica Panamericana; 1999.

12. IMSS. El Instituto Mexicano del Seguro Social. México: IMSS; 1943.

13. Zertuche-Muñoz, F. Historia del Instituto Mexicano del Seguro Social. Los primeros años 1943-1944. México: Instituto Mexicano del seguro Social; 1980.

14. Archivo Histórico de la Secretaría de Salud. Fondo ISET SSA/SUBSyA 02/073-33/1.

15. World Health Organization. Official records of the World Health Organization No. 2. Summary report on proceedings, minutes and finahacts of the International Health Conference Held in New York from 19 june to 22 july 1946. EE. UU: United Nations/World Health Organization; 1948.

16. González-Rivera M. Instituto de Salubridad y Enfermedades Tropicales de México: diez años de trabajo. Bol Ofic Sanitaria Panam. 1949;28: 702-718.

17. Varela G. Instituto de Salubridad y Enfermedades Tropicales." "Salud Publica Mex. 1964;6:1165-1171.

18. Archivo Histórico de la Secretaria de Salud. Fondo SSA, SUBSA C66E1.

19. Martínez-Báez M. El Instituto de Salubridad y Enfermedades Tropieales, 1969. An Soc Hist Cienc Tecnol. 1969;1:143-162.

20. Ramírez-Hernández JA, Guzmán-Bracho MC, Díaz-Quiñonez JA. Desde el ISET al InDRE. I. Instituto de Salubridad y Enfermedades Tropieales: génesis y primeros años, 1934-1940. Gac Med Mex. 2019;155(3): 322-327.

21. Colección de la Revista del Instituto de Salubridad y Enfermeđades Tropicales del Instituto de Diagnóstico y Referencia Epidemiológicos. México: Instituto de Diagnóstico y Referencia Epidemiológicos.

22. Marcial LD. Las publicaciones oficiales de la Secretaria de Salubriedad y Asistencia. Salud Publica Mex. 1983;25:489-497.

23. Instituto de Salubridad y Enfermedades Tropicales. Monografía №, 4 Bibliografía General 1939-1964. Rev Inst Salubridad Enferm Trop. 1964;24:1-151.

24. Mazzotti L. Dirección General de Institutos y Laboratorios. Salud Publica Mex. 1964;6:127-132.

25. Martínez-Cortés F. Introducción. En: Bustamante ME. Cinco persọajes de la Salud en México. México: Porrúa; 1986. 